\title{
GAMBARAN KINERJA BADAN USAHA MILIK DESA (BUMDES) DI KABUPATEN PATI
}

\author{
DESCRIPTION OF VILLAGE-OWNED ENTERPRISES (BUMDES) PERFORMANCE \\ IN PATI DISTRICT
}

Nurul Aeni

Badan Perencanaan Pembangunan Daerah Kabupaten Pati

Jl. Pati-Kudus Km. 3,5 Pati 59163, Jawa Tengah

Email: aeni_240884@yahoo.co.id

Diterima: 4 Nopember 2020, Direvisi: 25 Nopember 2020, Disetujui: 4 Desember 2020

\begin{abstract}
ABSTRAK
Kabupaten Pati memiliki jumlah desa yang cukup banyak dengan potensi yang belum dikembangkan secara optimal. Keberadaan BUMDes diharapkan dapat mengakselerasi pengembangan potensi desa sehingga dapat meningkatkan perekonomian masyarakat. Tujuan dari Penelitian ini adalah (1) Menggambarkan kondisi BUMDes di Kabupaten Pati dan (2) Mengidentifikasi permasalahan berdasarkan evaluasi terhadap kinerja BUMDes. Penelitian menggunakan pendekatan kuantitatif dan kualitatif secara bersama-sama. Pengamatan dilakukan terhadap data 401 BUMDes berdasarkan kriteria yang dikembangkan oleh Dinas Pemberdayaan Masyarakat Desa, Kependudukan, dan Catatan Sipil Provinsi Jawa Tengah. Hasil pengamatan selanjutnya dikonfirmasi melalui wawancara dengan narasumber yang relevan. Data yang didapat selanjutnya diolah secara kuantitatif dan kualitatif untuk menjawab pertanyaan penelitian. Hasil penelitian menunjukkan: (1) Pengembangan BUMDes belum optimal yang dibuktikan dengan sebagian besar BUMDes berada pada kriteria dasar. Simpan pinjam merupakan unit usaha yang paling banyak dijalankan, sementara itu hanya sedikit BUMDes yang memiliki usaha berbasis potensi desa. (2) Hambatan dalam pengembangan BUMDes ditemukan pada semua dimensi pengukuran kinerja, yaitu keterbatasan modal dan aset, administrasi dan pelaporan yang tidak tertib, keberadaan BUMDes belum memberikan dampak terhadap masyarakat desa, kelembagaan yang belum stabil, pengelolaan dan pengembangan usaha yang belum optimal, dan legalitas BUMDes yang belum kuat. (3) Adapun akar masalah dari belum optimalnya pengembangan BUMDes adalah keterbatasan kapasitas pengelola BUMDes, pengaruh konstelasi politik yang terjadi di desa, rendahnya dukungan pemerintah desa, serta pemilihan usaha yang belum berbasis potensi desa.
\end{abstract}

Kata-kata kunci: BUMDes, hambatan, kinerja, kriteria,

\section{ABSTRACT}

Pati District has many villages whose potentials optimally have not developed yet. The existence of Village-owned enterprises (BUMDes) is expected to accelerating rural potentials then to elevating the economics. This study aimed (1) to portray the existing condition of BUMDes in Pati District and (2) to identify the factor hampered BUMDes development based on their performance evaluation. Qualitative and quantitative approaches were used together in this study. Observations were conducted on the data of 401 BUMDes based on the criteria released by The office of village community empowerment, regional population, and civil registration of Central Java Province. Then, the data of observation were confirmed by interviewing several relevant 
informants. Then, they were analyzed qualitatively and quantitatively to answer the research questions. This study concluded: (1) The development of BUMDes has not optimized yet that was proved by majority BUMDes were on a basic level. Saving and loan was the business unit chosen by the greater number of BUMDes, while only a few BUMDes run local potential-based businesses. (2) The obstacles of BUMDes management were found in all dimensions, namely the lack of capital and asset, unsystematic reporting and administration, weak effect of BUMDes on village community, inappropriate BUMDes management and business development, weak BUMDes legality. (3) Furthermore, those obstacles were rooted in the lack of capacity of BUMDes management, the current political constellation in the villages, lack of support from the village government, and business unit selection that was not based on a local potential review.

Keywords: BUMDes, problems, performance, criteria,

\section{PENDAHULUAN}

Kesenjangan antarwilayah, diantaranya kesenjangan antara perkotaan dan perdesaan merupakan salah satu tantangan krusial dalam pembangunan di Indonesia. Kesenjangan kota dan desa tercipta sebagai hasil dari kebijakan pemerintahan di masa lalu dalam rangka menciptakan lapangan pekerjaan dan mengatasi kemiskinan melalui industrialiasi secara besar-besaran. Sebagai akibat dari kebijakan tersebut adalah munculnya dua kutub wilayah. Kawasan perkotaan menjadi pusat perindustrian, sementara perdesaan menjadi kawasan penopang dengan fokus kepada pertanian (Wilonoyudho, 2009). Pada saat yang sama, pemerintah juga mengimplementasikan revolusi hijau untuk meningkatkan produktivitas pertanian secara cepat, melalui intensifikasi pertanian. Melalui sudut pandang ekonomi, revolusi hijau terbukti mampu meningkatkan produktivitas pertanian, namun dari perspektif sosial, kebijakan tersebut menimbulkan kesenjangan antara pemilik lahan dan pekerja pertanian (Hekmatyar \& Nugroho, 2018). Selanjutnya, kesenjangan tersebut memicu pengangguran di kawasan perdesaan dan semakin menurunkan kualitas hidup penduduk. Kesenjangan antara desa dan kota dapat terlihat dari perbedaan kesejahteraan penduduk di kedua wilayah tersebut. Badan Pusat
Statistik (BPS) melaporkan bahwa tingkat kemiskinan desa di tahun 2019 sebesar $12,85 \%$ lebih tinggi dibandingkan tingkat kemiskinan kota sebesar 6,56\% (BPS, 2020). Kondisi tersebut dapat ditemukan di semua wilayah di Indonesia, termasuk Jawa Tengah. Berdasarkan BPS Jawa Tengah (2020), pada bulan September 2019, tingkat kemiskinan wilayah perdesaan Jawa Tengah sebesar 12,26\%, jauh melampaui tingkat kemiskinan di wilayah perkotaan sebesar 8,99\%.

Pembangunan perdesaan memiliki peran penting bagi pembangunan nasional karena sebagian besar penduduk Indonesia tinggal di kawasan perdesaan (Agunggunanto dkk, 2016). Namun demikian, penerapan pendekatan top-down terbukti kurang efektif karena justru menghambat kreativitas dan inovasi oleh pemerintah maupun masyarakat desa. Oleh karena itu, paradigma pembangunan kawasan pedesaan perlu diubah dengan mengedepankan partisipasi aktif masyarakat dalam seluruh proses pembangunan (Zuliyah, 2010). Selain itu, pembangunan perdesaan juga diharapkan mampu mengoptimalkan potensi yang dimiliki, baik berupa sumber daya alam, manusia, infrasruktur, maupun kapital (Chikmawati, 2019). Selanjutnya, pemberlakuan otonomi daerah menjadi momentum bagi perbaikan kualitas pembangunan perdesaan yang diperkuat melalui pemberlakuan 
Undang-Undang Nomor 6 Tahun 2014 tentang Desa. Berdasarkan perundangan tersebut, pembangunan desa dianggap sebagai upaya untuk memperkuat ketahanan desa melalui pemberdayaan masyarakat serta pengembangan potensi yang dimiliki (Rozikin, 2019).

Kawasan perdesaan pada umumnya memiliki potensi yang melimpah, khususnya sumber daya alam. Namun demikian, rendahnya kualitas sumber daya manusia serta minimmya fasilitas maupun sarana prasarana penunjang menjadi tantangan dalam pengelolaan potensi desa dalam rangka memperkuat ketahanan ekonomi. Oleh karena itu, pemerintah menginisiasi pendirian Badan Usaha Milik Desa atau BUMDes sebagai suatu lembaga ekonomi yang dapat menampung hasil aktivitas ekonomi masyarakat (Darwita \& Redana, 2018). Permendesa PDTT Nomor 4 Tahun 2015 tentang Pendirian BUMDes menyebutkan bahwa keberadaan BUMDes krusial bagi pembangunan ekonomi desa karena memiliki beberapa peran, diantaranya mengoptimalkan potensi dan aset desa demi kesejahteraan desa, mengembangkan kerja sama dengan pihak eksternal, menciptakan jaringan pasar yang selaras dengan kebutuhan masyarakat desa, membuka lapangan kerja, serta meningkatkan pendapatan masyarakat dan PAD. Berdasarkan beberapa peran tersebut, dapat dinyatakan bahwa BUMDes menjalankan dua fungsi secara bersama-sama, yaitu fungsi ekonomi dan fungsi sosial. Fungsi ekonomi dapat dilihat dari bentuk BUMdesa sebagai sebuah lembaga ekonomi yang berorientasi pada profit. Sementara itu, BUMDesa juga dapat dikatakan sebagai lembaga sosial karena aktivitas yang dilakukan hendaknya sesuai dengan kepentingan dan kebutuhan masyarakat desa (Ridlwan, 2014).
Beberapa penelitian telah membuktikan bahwa BUMDes mampu meningkatkan kualitas hidup masyarakat perdesaan di beberapa wilayah. Penelitian oleh Darwita dan Redana (2018) membuktikan bahwa BUMDes di Desa Tejakula telah berhasil melaksanakan peran pengembangan potensi dan pemberdayaan masyarakat melalui pelaksanaan beberapa unit usaha seperti simpan pinjam, pengelolaan sampah dan hutan desa. Penelitian lain oleh Kinasih dkk. (2020) menyatakan bahwa BUMDes di Desa Morosari terbukti meningkatkan perekonomian masyarakat di desa tersebut. BUMDes di Desa Morosari memiliki usaha pengolahan keripik dengan mengambil bahan baku dari usaha perkebunan penduduk sekitar. Selain itu, unit usaha tersebut juga berhasil menciptakan lapangan kerja baru. Bagi pemerintah desa, keberadaan BUMDes juga menjadi salah satu sumber pendapatan asli desa sehingga tidak terlalu bergantung kepada ADD dan DD. Sementara itu, penelitian oleh Prasetyo (2016) mengungkapkan bahwa BUMDes di Desa Pejambon berperan dalam pembangunan di desa tersebut melalui pembangunan infrastruktur. Keuntungan yang diperoleh dari BUMDes dimanfaatkan oleh pemerintah desa untuk pembangunan fasilitas publik yang menunjang kegiatan ekonomi dan sosial masyarakat desa.

Kabupaten Pati merupakan wilayah di Jawa Tengah dengan jumlah desa terbanyak setelah Kabupaten Cilacap. Desa di Kabupaten Pati berjumlah 401 unit dan tersebar di 21 kecamatan. Dengan wilayah desa yang cukup luas tersebut, sudah seharusnya pembangunan di Kabupaten Pati difokuskan di wilayah perdesaan. Sebagaimana tercantum dalam RPJMD Kabupaten Pati Tahun 2017-2022 bahwa parameter keberhasilan pembangunan desa adalah skor Indeks Desa 
Membangun (IDM). Rata-rata nilai IDM di tahun 2019 sebesar 0.677, dimana nilai tersebut meningkat dari rata-rata nilai IDM di tahun 2017 sebesar 0,644. Peningkatan tersebut dapat menjadi indikasi keberhasilan pembangunan desa di Kabupaten Pati. Selanjutnya, pengamatan terhadap ketiga dimensi IDM, dapat dinyatakan bahwa Indeks Ketahanan Ekonomi (IKE) memiliki nilai paling rendah dibandingkan ketahanan sosial dan ketahanan lingkungan. Berdasarkan kondisi tersebut, seharusnya ekonomi menjadi prioritas pembangunan desa di Kabupaten Pati. Hingga 2020, seluruh desa di Kabupaten Pati telah memiliki BUMDes. Keberadaan BUMDes tersebut diharapkan dapat mengakselerasi pembangunan desa, khususnya bidang ekonomi. Selanjutnya keberhasilan dalam pembangunan ekonomi diharapkan dapat mendorong keberhasilan pada aspek lainnya, dan selanjutnya meningkatkan kualitas kehidupan masyarakat desa. Namun demikian, kajian mengenai kinerja BUMDes di Kabupaten Pati serta kelemahan yang muncul dalam pengelolaan BUMDes belum pernah dilakukan. Berdasarkan latar belakang tersebut, tujuan dari penelitian ini adalah (1) Menggambarkan kondisi BUMDes di Kabupaten Pati dan (2) Mengidentifikasi permasalahan yang dihadapi BUMDes berdasarkan evaluasi terhadap kinerja BUMDes.

\section{METODE}

Penelitian ini menggunakan kombinasi pendekatan kuatitatif dan kualitatif secara bersama-sama. Penelitian berlokasi di Kabupaten Pati dengan objek penelitian adalah 401 BUMDes di Kabupaten Pati. Data utama yang digunakan dalam penelitian berupa data sekunder, yaitu hasil penilaian kinerja BUMDes tahun 2018. Penilaian BUMDes tersebut berdasarkan Klasifikasi Perkem- bangan BUMDes yang dikeluarkan oleh Dinas Pemberdayaan Masyarakat Desa, Kependudukan dan Pencatatan Sipil Provinsi Jawa Tengah. Klasifikasi tersebut didasarkan pada enam dimensi, yaitu (1) Kelembagaan, (2) Aturan, (3) Usaha, (4) Administrasi, Pelaporan, dan Pertanggungjawaban, (5) Permodalan dan aset, serta (6) Dampak BUMDesa terhadap masyarakat dan desa. Enam dimensi tersebut memiliki bobot yang berbeda dimana Usaha merupakan dimensi dengan bobot tertinggi sebesar 25\%. Dimensi Kelembagaan dan Dimensi Dampak BUMDesa terhadap masyarakat desa memiliki bobot masing-masing 20\%. Permodalan dan Aset merupakan dimensi dengan bobot $15 \%$ dan Dimensi Aturan serta Dimensi Administrasi, Pelaporan, dan Pertanggungjawaban memiliki bobot terendah sebesar $10 \%$. Setiap dimensi memiliki beberapa parameter dimana setiap parameter memiliki nilai minimal 1 dan maksimal 4. Metode kuantitatif deskriptif diimplemenasikan dengan menghitung total skor dari keenam dimensi pengukuran kinerja BUMDes. Selanjutnya, BUMDes diklasifikasikan dalam empat tingkat perkembangan, yaituDasar (25-49), Tumbuh (50-74), Berkembang (75-85), dan Maju (>85).

Analisis capaian kinerja BUMDes juga dilakukan untuk setiap dimensi. Hal tersebut dimaksudkan untuk mengidentifikasi dimensi yang masih membutuhkan pengembangan. Analisis terhadap dimensi kinerja BUMDes dilakukan dengan menghitung rata-rata nilai pengukuran parameter di setiap dimensi, sehingga didapatkan kisaran nilai 1,00 hingga 4,00. Semakin tinggi nilai yang didapatkan, semakin baik pula kinerja BUMDes pada dimensi tersebut. Selanjutnya dilakukan triangulasi untuk mendapatkan mengelaborasi permasalahan yang terdapat di setiap dimensi. Triangaluasi dilakukan melalui metode 
wawancara dengan narasumber yang relevan. Narasumber yang dimaksud adalah Kepala Seksi (Kasi) Pengembangan Lembaga Ekonomi dan Kelompok Masyarakat Desa (Informan 1), Kasi Pengembangan Ekonomi dan TTG Bidang Pengembangan Ekonomi dan TTG (Informan 2) dari Dinas Pemberdayaan Masyarakat Desa Kabupaten Pati dan Koordinator pendamping desa Kabupaten Pati yang bertanggung jawab untuk pengembangan BUMDes (Informan 3). Selain itu, triangulasi juga dilakukan dengan melakukan pengamatan terhadap data BUMDes yang didapatkan dari Dinas Pemberdayaan Masyarakat Desa (Dispermades) Kabupaten Pati.

\section{HASIL DAN PEMBAHASAN \\ Gambaran Badan Usaha Milik Desa di Kabupaten Pati}

Berdasarkan hasil wawancara dengan Informan 1 didapatkan informasi bahwa Kabupaten Pati mulai menginisiasi berdirinya BUMDes di tahun 2013 berdasarkan Peraturan Daerah Kabupaten Pati Nomor 4 Tahun 2013 tentang Tata Cara Pembentukan dan Pengelolaan BUMDes. Berdasarkan peraturan tersebut, disebutkan bahwa pembentukan BUMDes di setiap desa diawali melalui Musyawarah Desa (Musdes) yang kemudian ditetapkan dengan Peraturan Desa (Perdes) sebagai landasan hukumnya. Berbeda dengan kabupaten lain yang menginisiasi pendirian BUMDes secara bertahap, Kabupaten Pati mendorong pendirian BUMDes secara serentak di seluruh desa. Berdasarkan data dari Dispermades Kabupaten Pati, pada tahun 2018 terdapat 355 unit BUMDes yang aktif beroperasi atau mencakup sekitar 88,53\% dari total BUMDes di Kabupaten Pati. Keberadaan BUMDes aktif di setiap kecamatan memiliki persentase yang berbeda sebagaimana ditampilkan pada Gambar 1.

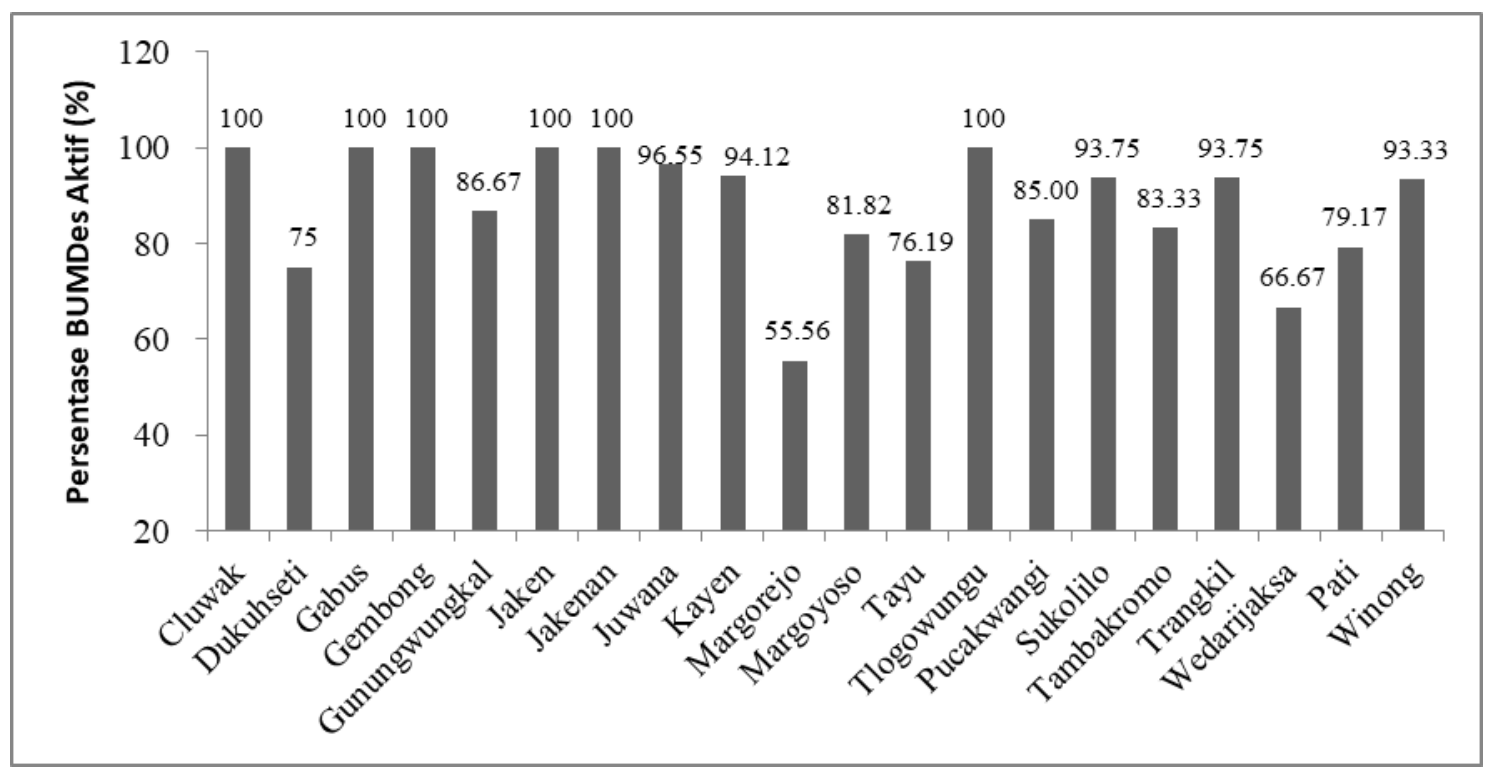

Gambar 1.

Persentase Persebaran BUMDes Aktif Per Kecamatan

Beberapa kecamatan menunjukkan kinerja pengelolaan BUMDes baik yang ditunjukkan dengan seluruh
BUMDes di wilayah tersebut berstatus aktif. Kecamatan tersebut adalah Cluwak, Gabus, Gembong, Jakenan, dan 
Tlogowungu. Sementara itu, beberapa kecamatan lainnya menunjukkan kinerja pengembangan BUMDes relatif kurang berhasil yang ditunjukkan dengan rendahnya persentase BUMDes aktif di wilayah tersebut. Tiga kecamatan dengan persentase BUMDes tidak aktif terendah adalah Margorejo (55,56\%), Wedarijaksa $(66,67 \%)$ dan Dukuhseti $(75 \%)$.

Selain penilaian terhadap status keaktifan, kinerja BUMDes juga dapat diukur berdasarkan klasifikasi pengembangan BUMDes yang disusun oleh Dinas
Pemberdayaan Desa, Kependudukan dan Catatan Sipil Provinsi Jawa Tengah. Berdasarkan klasifikasi tersebut, dapat dinyatakan bahwa sebagian besar BUMDes di Kabupaten Pati berada pada kriteria dasar berjumlah 308 unit atau mencakup 76,81\% dari total BUMDes. BUMDes pada kriteria dasar dapat ditemukan di seluruh kecamatan dengan jumlah yang berbeda. Persebaran BUMDes berdasarkan kriteria pengembangan BUMDes di tiap kecamatan ditampilkan pada Tabel 1.

Tabel 1.

Jumlah BUMDes Berdasarkan Kriteria Pengembangan BUMDes Tiap Kecamatan Tahun 2018

\begin{tabular}{|c|c|c|c|c|c|}
\hline \multirow{2}{*}{ Kecamatan } & \multicolumn{4}{|c|}{ Jumlah BUMDes berdasarkan kriteria } & \multirow{2}{*}{ Total } \\
\hline & Dasar & Tumbuh & Berkembang & Maju & \\
\hline Batangan & 14 & 3 & & 1 & 18 \\
\hline Cluwak & 11 & 2 & & & 13 \\
\hline Dukuhseti & 7 & 5 & & & 12 \\
\hline Gabus & 20 & 4 & & & 24 \\
\hline Gembong & 11 & 0 & & & 11 \\
\hline Gunungwungkal & 12 & 3 & & & 15 \\
\hline Jaken & 14 & 6 & 1 & & 21 \\
\hline Jakenan & 21 & 2 & & & 23 \\
\hline Juwana & 25 & 4 & & & 29 \\
\hline Kayen & 12 & 5 & & & 17 \\
\hline Margorejo & 13 & 5 & & & 18 \\
\hline Margoyoso & 19 & 3 & & & 22 \\
\hline Tayu & 14 & 7 & & & 21 \\
\hline Tlogowungu & 10 & 5 & & & 15 \\
\hline Pucakwangi & 14 & 6 & & & 20 \\
\hline Sukolilo & 12 & 4 & & & 16 \\
\hline Tambakromo & 15 & 3 & & & 18 \\
\hline Trangkil & 11 & 5 & & & 16 \\
\hline Wedarijaksa & 13 & 5 & & & 18 \\
\hline Pati & 19 & 5 & & & 24 \\
\hline Winong & 21 & 9 & & & 30 \\
\hline Total & 308 & 91 & 1 & 1 & 401 \\
\hline
\end{tabular}

Sumber: Dispermades Kab. Pati, diolah (2019)

Berdasarkan Tabel 1 dapat dinyatakan bahwa BUMDes kriteria dasar paling banyak ditemukan di Kecamatan Juwana sebanyak 25 unit atau mencakup $8,12 \%$ dari total BUMDes kriteria dasar.
Selanjutnya, Kecamatan Jakenan dan Winong juga memiliki jumlah BUMDes kriteria dasar cukup banyak, yaitu masingmasing 21 unit atau mencakup 6,82\% dari total BUMDes kriteria dasar. Selanjutnya, 
terdapat 91 unit atau sekitar 22,69\% BUMDes di Kabupaten Pati yang berada pada kriteria tumbuh. Kecamatan dengan jumlah BUMDes kriteria Tumbuh terbanyak adalah Kecamatan Winong (9 unit BUMDes) dengan persentase sekitar 9,89\% dari total BUMDes kriteria Tumbuh. Selain itu, terdapat Kecamatan Tayu dan Kecamatan Jaken yang memiliki BUMDes kriteria Tumbuh cukup banyak. Selanjutnya terdapat Kecamatan Gembong tidak memiliki BUMDes dalam kriteria Tumbuh karena seluruh BUMDes berada pada kriteria Dasar. Selain Gembong, terdapat Kecamatan Cluwak dan Kecamatan Jakenan yang memiliki jumlah BUMDes kriteria Tumbuh relif kecil dengan persentase masing-masing sekiar
2\% dari total BUMDes kriteria Tumbuh. Sementara itu hanya masing-masing satu unit BUMDes yang berada pada kriteria Berkembang dan Maju. BUMDes kriteria Berkembang dapat ditemukan di Kecamatan Jaken, sedangkan BUMDes kriteria Maju berada di Kecamatan Batangan.

Pengamatan terhadap jenis usaha BUMDes menunjukkan sekitar 148 unit atau 36, 91\% BUMDes menjalankan lebih dari satu unit usaha. Selanjutnya dilihat dari jenisnya, sebagian besar BUMDes, sekitar 74,56\% menjalankan usaha simpan pinjam. Gambaran jenis usaha yang dijalankan oleh BUMDes di Kabupaten Pati dapat dilihat pada Tabel 2.

Tabel 2.

Jenis Usaha yang Dilakukan BUMDes per Kecamatan

\begin{tabular}{|c|c|c|c|c|c|c|c|c|c|}
\hline \multirow[b]{2}{*}{ Kecamatan } & \multicolumn{9}{|c|}{ Jenis Usaha yang dikelola BUMDes berdasarkan Kecamatan } \\
\hline & $\begin{array}{l}\text { Simpan } \\
\text { Pinjam }\end{array}$ & $\begin{array}{l}\text { Jasa Non- } \\
\text { Simpan } \\
\text { Pinjam }\end{array}$ & $\begin{array}{l}\text { Pengadaan } \\
\text { Air bersih }\end{array}$ & Pertanian & $\begin{array}{c}\text { Perdagang } \\
\text { an }\end{array}$ & Wisata & & $\begin{array}{l}\text { Pengelolaan } \\
\text { Sampah }\end{array}$ & $\begin{array}{l}\text { Produksi } \\
\text { Barang }\end{array}$ \\
\hline Batangan & 15 & 3 & 0 & 0 & 4 & & 0 & 1 & 1 \\
\hline Cluwak & 13 & 3 & 5 & 0 & 0 & & 0 & 0 & 0 \\
\hline Dukuhseti & 12 & 3 & 0 & 1 & 3 & & 0 & 0 & 0 \\
\hline Gabus & 23 & 1 & 5 & 1 & 1 & & 0 & 0 & 0 \\
\hline Gembong & 11 & 5 & 4 & 2 & 5 & & 2 & 0 & 1 \\
\hline Gunungwungkal & 12 & 4 & 1 & 1 & 1 & & 0 & 0 & 0 \\
\hline Jaken & 17 & 6 & 1 & 1 & 0 & & 0 & 0 & 0 \\
\hline Jakenan & 23 & 1 & 3 & 4 & 2 & & 0 & 0 & 0 \\
\hline Juwana & 19 & 7 & 0 & 1 & 5 & & 0 & 2 & 0 \\
\hline Kayen & 13 & 8 & 2 & 1 & 1 & & 0 & 1 & 0 \\
\hline Margorejo & 12 & 2 & 2 & 3 & 2 & & 0 & 1 & 0 \\
\hline Margoyoso & 5 & 5 & 0 & 0 & 4 & & 0 & 2 & 0 \\
\hline Tayu & 8 & 4 & 2 & 8 & 1 & & 0 & 1 & 0 \\
\hline Tlogowungu & 11 & 8 & 7 & 2 & 1 & & 1 & 0 & 0 \\
\hline Pucakwangi & 17 & 8 & 2 & 2 & 3 & & 2 & 1 & 1 \\
\hline Sukolilo & 12 & 5 & 0 & 0 & 1 & & 0 & 0 & 1 \\
\hline Tambakromo & 13 & 3 & 4 & 1 & 3 & & 0 & 0 & 0 \\
\hline Trangkil & 10 & 6 & 0 & 0 & 1 & & 0 & 1 & 0 \\
\hline Wedarijaksa & 12 & 5 & 1 & 2 & 0 & & 0 & 0 & 0 \\
\hline Pati & 17 & 2 & 1 & 0 & 2 & & 0 & 0 & 0 \\
\hline Winong & 24 & 8 & 5 & 4 & 0 & & 0 & 1 & 1 \\
\hline Total & 299 & 97 & 45 & 34 & 40 & & 5 & 11 & 5 \\
\hline
\end{tabular}

Sumber: Dispermades Kab. Pati, diolah (2019)

BUMDes yang menjalankan unit usaha simpan pinjam tersebar di seluruh kecamatan dengan intensitas yang berbeda. Persentase BUMDes dengan usaha simpan pinjam tertinggi berada di Kecamatan Cluwak, Dukuhseti, Gembong 
dan Jakenan dimana seluruh BUMDes di wilayah tersebut memiliki usaha simpan pinjam. Sementara persentase BUMDes dengan unit usaha simpan pinjam terkecil ditemukan di Kecamatan Tayu $(38,1 \%)$ dan Margoyoso (22,7\%). Unit usaha selanjutnya yang banyak dijalankan oleh BUMDes adalah usaha jasa non-simpan pinjam dengan persentase mencapai 24,19\% dari total BUMDes di Kabupaten Pati. Unit usaha ini dapat ditemukan di semua kecamatan dengan jumlah terbanyak berada di Kecamatan Kayen, Tlogowungu, Pucakwangi, dan Winong. Unit usaha jasa non-simpan memiliki jenis yang beragam, namun sebagian besar BUMDes memilih usaha persewaan alat/mesin pertanian, pengelolaan pasar desa, transportasi, dan jasa perbankan. Sebesar 11,22\% BUMDes menjalankan usaha pengelolan air bersih. BUMDes yang memiliki unit usaha tersebut pada umumya berada di desa yang memiliki program PAMSIMAS. Usaha perdagangan juga banyak dijalankan oleh BUMDes di Kabupaten Pati dengan persentase mencapai $9,98 \%$. Jenis komoditas yang diperdagangkan pada umumnya adalah barang kebutuhan sehari-hari serta pupuk atau obat pertanian.

Kabupaten Pati merupakan wilayah dengan potensi pertanian dan perikanan yang relatif besar. Namun demikian, tampaknya hal tersebut belum dapat ditangkap oleh BUMDes. Tercatat hanya sekitar 8,48\% BUMDes yang menjalankan usaha di bidang pertanian, terutama peternakan dan perikanan. Keberadaan BUMDes jenis ini hanya ditemukan di 15 kecamatan, dimana Tayu merupakan kecamatan dengan BUMDes dengan unit usaha pertanian paling banyak. Secara berurutan Pengelolaan sampah, Wisata, dan Produksi merupakan unit usaha yang paling sedikit dijalankan oleh BUMDes di Kabupaten Pati. Pengelolaan sampah hanya dijalankan oleh sekitar 2,74\%
BUMDes dan hanya terdapat di 9 kecamatan. Selanjutnya unit usaha wisata dan produksi hanya dijalankan masingmasing oleh sekitar 1,25\% BUMDes. Unit usaha Wisata hanya ditemukan di 3 kecamatan, sementara unit usaha produksi ditemukan di 5 kecamatan. Hasil penelitian tersebut selaras dengan penelitian di Jawa Tengah yang menyimpulkan bahwa bidang jasa merupakan unit usaha yang paling banyak dipilih oleh BUMDes yang menjadi responden penelitian dan setelahnya terdapat usaha pengelolaan air bersih. Sementara bidang pertanian dan industri kreatif tidak banyak diminati oleh BUMDes untuk dijadikan unit usaha (Priyanto dkk, 2019).

\section{Identifikasi Permasalahan Berdasarkan Evaluasi Kinerja BUMDes}

Identifikasi terhadap permasalahan yang dihadapi oleh BUMDes di Kabupaten Pati dilakukan berdasarkan enam dimensi dalam kriteria pengembangan BUMDes yang disusun oleh Dinas Pemberdayaan Masyarakat Desa, Kependudukan, dan Pencatatan Sipil Provinsi Jawa Tengah. Keenam dimensi tersebut adalah (1) Kelembagaan, (2) Aturan, (3) Usaha, (4) Administrasi, Pelaporan, dan Pertanggungjawaban, (5) Permodalan dan Aset, dan (6) Dampak BUMDes Terhadap Masyarakat dan Desa. Hasil analisis terhadap enam dimensi tersebut menunjukkan bahwa sebagian besar BUMDes di Kabupaten Pati memiliki kelemahan di semua dimensi, namun dengan intensitas yang berbeda.

Hasil pengamatan menunjukkan Permodalan dan Aset merupakan dimensi yang terlemah dibandingkan dengan dimensi lain. Nilai rata-rata seluruh parameter pada dimensi ini adalah 1,00 dari nilai maksimal 4,00. Berdasarkan data dari Dispermades Kabupaten Pati dapat dilihat bahwa jumlah modal usaha yang dimiliki oleh BUMDes di Kabupaten Pati 
berkisar puluhan hingga ratusan juta rupiah, dimana sebagian besar BUMDes memiliki aset kurang dari 200 juta. Modal usaha yang dimiliki oleh BUMDes pada umumnya hanya berasal dari penyertaan modal desa, namun jumlah yang diberikan relatif kecil untuk pengelolaan sebuah usaha. Informan 3 menyatakan bahwa hal tersebut menandakan rendahnya komitmen pemerintah desa untuk mengembangkan BUMDes. Pada dasarnya nilai penyertaan modal desa untuk BUMDes telah diatur dalam perundangan. Namun pada kenyataaannya, sebagian besar pemerintah desa tidak menjalankan ketentuan tersebut. Nilai modal usaha yang disertakan untuk BUMDes bisanya merupakan SILPA APBD desa. Kondisi tersebut selanjutnya berdampak pada rendahnya kepemilikan aset oleh BUMDes. Sebagian besar BUMDes di Kabupaten Pati belum memiliki kantor yang permanen dan inventaris kantor yang memadai. Bahkan, rendahnya modal yang dimiliki oleh BUMDes menjadi kendala utama BUMDes untuk menggaji pengurus. Informan 2 menyatakan bahwa pengurus BUMDes pada umumnya disebut sebagai relawan BUMDes, dimana mereka tidak mendapatkan gaji secara kontinyu dan mengelola BUMDes merupakan pekerjaan sampingan. Hal tersebut yang menjadi salah satu penyebab tidak optimalnya pengelolaan BUMDes. Kondisi yang terjadi pada sebagian BUMDes di Kabupaten Pati juga ditemukan pada beberapa BUMDes di wilayah lain. Sebuah BUMDes di Desa Cokrokembang, Kabupaten Pacitan mengalami kendala permodaan karena hanya bergantung kepada penyertaan modal dari pemerintah desa yang diturunkan setiap tahun sekali (Rahmadanik, 2018). Sementara itu, BUMDes di Desa Kopeng juga mengalami keterbatasan modal dikarenakan bantuan modal yang diberikan pemerintah desa bersifat tidak tentu dan hanya diberikan ketika BUMDes dirasakan membutuhkan modal. Kondisi tersebut menghambat pengembangan usaha BUMDes yang diperberat dengan rendahnya partisipasi beberapa pengurus BUMDes dalam penyusunan program kerja (Ferosa \& Hapsari, 2020).

Administrasi, Pelaporan, dan Pertanggungjawaban merupakan dimensi terlemah kedua. Nilai rata-rata dari seluruh parameter pada dimensi tersebut adalah 1,33. Terdapat beberapa permasalahan utama pada dimensi ini antara lain proses pembukuan yang tidak teratur. Sebagian besar BUMDes di Kabupaten Pati tercatat tidak melakukan pembukuan secara rutin serta tidak melaksanakan pertangggungjawaban keuangan dan usaha melalui Musdes. Selain itu, pembukuan yang dilakukan oleh sebagian besar BUMDes masih bersifat sederhana dan relatif belum tertib. Pelaporan keuangan yang kurang tertib dan terlalu sederhana relatif kurang dapat menggambarkan kondisi BUMDes yang sebenarnya (Dwidiyantini dkk, 2017). Kelemahan dalam sistem pelaporan keuangan BUMDes merupakan cerminan rendahnya kapasitas pengelola BUMDes dan hal ini merupakan salah satu hambatan terbesar dalam pengelolaan BUMDes. Berdasarkan informasi dari Informan 3, pada umumya pengurus BUMDes memiliki pendidikan setara SMA atau sederajat dan tidak memiliki latar belakang pengelolaan usaha sebelumnya. Selain itu, mengelola BUMDes pada umumya merupakan pekerjaan sampingan sehingga para pengelola tidak bisa mendedikasikan waktu sepenuhnya untuk mengurus BUMDes. Dalam rangka meningkatkan kapasitas pengelola BUMDes, Dispermades Kabupaten Pati secara kontinyu memiliki kegiatan peningkatan kapasitas pengurus BUMDes. Informan 1 menyatakan setiap tahun dilaksanakan pelatihan manajerial BUMDes dengan kapasitas mencapai 100 
peserta dengan sasaran utamanya pengurus BUMDes yang berada pada kriteria dasar. Namun oleh Informan 3, pelatihan tersebut dinilai kurang efektif karena belum sesuai dengan kebutuhan BUMDes. Selain itu, evaluasi dan pendampingan tidak dilaksanakan setelah penyelenggaraan pelatihan sehingga peningkatan kapasitas para pengurus BUMDes tidak terukur.

Pengelolaan BUMDes di Kabupaten Pati tidak bisa dilepaskan dari konstelasi politik yang ada di desa tersebut. Menurut Informan 2, personel yang terpilih untuk mengelola BUMDes merupakan tokoh yang dekat dengan kepala desa yang sedang berkuasa. Dalam struktur kepengurusan BUMDes, kepala desa memiliki posisi cukup strategis sebagai dewan penasehat. Namun dalam pelaksanaanya, kepala desa menjalankan tugas tersebut melebihi kewenangan yang dimiliki. Hasil penelitian Firdaus (2018) menyimpulkan bahwa kepala desa merupakan pihak yang memiliki kekuasaan paling besar dalam pengelolaan BUMDes. Hal tersebut dapat tercermin dari peran kepala desa dalam menentukan pengelola, unit usaha yang dijalankan, menjalin kesepakatan dengan pihak lain, serta pemanfaatan keuntungan usaha BUMDes. Kondisi ini berpotensi mengancam keberlangsungan BUMDes karena kepala desa merupakan jabatan politis dengan jenjang waktu tertentu. Pergantian kekuasaan di desa sangat berpotensi menimbulkan konflik dan perubahan kebijakan pengelolaa BUMDes yang pada akhirnya dapat melemahkan kelembagaan BUMDes.

Dimensi ketiga yang menjadi kelemahan pengembangan BUMdes di Kabupaten Pati adalah dampak BUMDes terhadap masyarakat desa dengan nilai rata-rata sebesar 1,67. Dampak BUMDes terhadap masyarakat dapat dibedakan menjadi tiga, yaitu dampak ekonomi, sosial, dan pembangunan desa. Bagi masyarakat desa, keberadaan BUMDes dirasakan cukup memberikan dampak bagi usaha yang dijalankan oleh masyarakat. Walaupun pada beberapa desa, dampak tersebut hanya dinikmati oleh beberapa golongan saja. Informan 2 menyatakan bahwa kondisi politik di desa mempengaruhi pengembangan BUMDes. Sebagian penduduk desa menganggap BUMDes sebagai bagian dari kepala desa yang sedang berkuasa, sehingga mereka terkadang enggan untuk memanfaatkan BUMDes. Hasil penelitian tersebut sejalan dengan kondisi yang terjadi di BUMDes di Kabupaten Gunungkidul. Manfaat dari keberadaan BUMDes di wilayah tersebut belum dirasakan oleh masyarakat sekitar. Keuntungan yang didapatkan oleh BUMDes sebagian besar masuk ke kas desa, namun manfaatnya secara langsung kurang dirasakan oleh masyarakat. Selain itu, konflik dalam pengelolaan BUMDes menjadikan beberapa dusun tidak dapat mengakses manfaat BUMDes dengan optimal (Anggraeni, 2016). Pengelolaan usaha BUMDes yang dilakukan secara profesional sesuai dengan ketentuan yang berlaku terbukti memberikan manfaat bagi masyarakat desa. Kondisi tersebut terjadi di Desa Pejambon, Kabupaten Bojonegoro. Masyarakat di desa tersebut menyatakan bahwa mereka memperoleh manfaat dari keberadaan BUMDes di desa tersebut utamanya berupa perbaikan fasilitas publik (Prasetyo, 2016).

Informan 3 menyatakan bahwa, terdapat beberapa BUMDes yang telah berhasil memperbaiki kelembagaannya sehingga mampu memberikan kontribusi terhadap perekonomian masyarakat desa. Salah satu BUMDes tersebut berada di Desa Klakahkasihan, Kecamatan Gembong yang berhasil mengembangkan unit usaha pariwisata bahkan berhasil menyerap tenaga kerja. Lebih lanjut, berdasarkan informan tersebut, BUMDes yang berhasil memberikan kontribusi 
secara ekonomi pada umumnya adalah BUMDes berhasil mengidentifikasi potensi desa dan mengembangkannya sebagai unit usaha. Berbeda dengan dampak ekonomi, masyarakat desa beranggapan keberadaan BUMDes tidak memberikan dampak terhadap kehidupan sosial dan pembangunan desa. Menurut Informan 1, sebagian besar BUMDes di Kabupaten Pati memiliki keuntungan usaha rendah, sehingga keuntungan tersebut tidak diberikan ke desa untuk pembiyaan pembangunan.

Dimensi keempat yang menjadi titik kelemahan pengembangan BUMDes di Kabupaten Pati adalah kelembagaan. Nilai rata-rata seluruh parameter pada dimensi ini adalah 1,83 dari nilai maksimal. Seluruh BUMDes di Kabupaten Pati didirikan melalui Musyawarah Desa (Musdes) dan memiliki sruktur organisasi sesuai dengan ketentuan yang berlaku yang ditetapkan melalui Surat Keputusan (SK) Kepala Desa. Namun demikian, semua proses tersebut tidak terdokumentasi dengan baik. Menurut Informan 2 pendirian BUMDes di Kabupaten Pati pada awalnya cenderung dipaksakan dan tanpa persiapan yang matang. Pemerintah Desa belum diberikan pemahaman yang cukup komprehensif tentang mekanisme pendirian BUMDes. Selain itu, secara kapasitas personel yang ditunjuk untuk mengelola BUMDes belum memiliki kapasitas manajerial yang memadai untuk mengelola. Ketidaksiapan dalam pendirian BUMDes juga terlihat dari pemilihan unit usaha yang akan dijalankan. Unit usaha yang dipilih pada umumnya adalah unit usaha yang telah ada sebelum pembentukan BUMDes tanpa mempertimbangkan potensi yang dimiliki desa.

Selanjutnya, sebagian besar BUMDes di Kabupaten Pati tidak melakukan perencanaan program kerja yang digunakan sebagai pedoman pengembangan BUMDes. Kondisi tersebut dikonfirmasi oleh Informan 3 yang menyatakan bahwa banyak BUMDes yang tidak memiliki arah yang jelas dalam pengembangan BUMDes sehingga usaha yang dijalankan tidak berkembang bahkan akhirnya beberapa diantaranya tidak beroperasi. Kelemahan dimensi kepengurusan juga dapat dilihat dari ketiadaan tugas pokok dan fungsi (Tupoksi) yang tercatat yang kemudian menjadi pedoman bagi pengurus dalam melaksanakan tugasnya. Tidak maksimalnya kinerja pengurus dalam mengelola BUMDes selanjutnya berdampak pada kinerja pengembangan BUMDes yang dapat dilihat dari kemampuan dalam menjalin kerjasama dengan BUMDes lain maupun pihak ketiga. Berdasarkan Informan 1, pemerintah daerah telah menginisiasi terbentuknya BUMDes bersama (BUMDesma) yang merupakan kumpulan dari beberapa BUMDes. Telah ada tujuh BUMDesma yang terbentuk, namun hanya satu unit BUMDesmas yang masih beroperasi. Menurut Informan 1, tanggung jawab pengembangan BUMDesma tidak berada dalam bidang yang sama, sehingga pengembangan BUMDes dan BUMDesma tidak berjalan secara komprehensif. Selain itu, informan 3 menambahkan dasar pembentukan BUMDesma pada umumnya dilakukan tanpa persiapan yang memadai dan didasarkan pada intensi untuk mendapatkan tambahan modal dari instansi pemerintah vertikal.

Dimensi selanjutnya yang menjadi titik kelemahan pengembangan BUMDes di Kabupaten Pati adalah usaha dengan nilai rata-rata sebesar 2,00 dari nilai maksimal 4,00. Sebagian BUMDes di Kabupaten Pati hanya menjalankan satu jenis usaha. Selain itu, terdapat kecenderungan BUMDes tidak mempu menjalankan unit usaha yang dimiliki secara efisien. Hal tersebut tersebut dapat dilihat dari pendapatan usaha yang didapatkan. Terdapat 293 unit atau sekitar 
73\% BUMDes yang berhasil membukukan pendapatan di tahun 2019. Nilai pendapatan yang didapatkan bervariasi dari Rp 150.000,00 hingga Rp 73.400.000 per tahun dengan rata-rata pendapatan sekitar Rp 16.000.000,00 per tahun. Nilai pendapatan yang didapatkan tersebut relatif kecil jika digunakan untuk pengembangan BUMDes. Berdasarkan Tabel 2 terlihat bahwa usaha yang paling banyak dijalankan adalah simpan pinjam. Informan 1 menambahkan bahwa simpan pinjam merupakan usaha yang lebih mudah dikelola dibandingkan unit usaha lainnya. Selain itu, usaha simpan pinjam pada umumnya sudah ada sebelum pendirian BUMDes. Waktu persiapan pendirian BUMDes yang relatif pendek, membuat pengurus memilih unit usaha di desa yang telah beroperasi sebelumnya, yaitu simpan pinjam. Kabupaten Pati memiliki potensi yang cukup melimpah di beberapa sektor, terutama pertanian (pertanian, peternakan, dan perikanan). Namun demikian hanya sebagian kecil BUMDes yang memiliki usaha di sektor tersebut namun hasilnya juga tidak maksimal. Kondisi yang terjadi di Kabupaten Pati juga terjadi di Kabupaten Jepara. Hampir seluruh BUMDes di wilayah tersebut memiliki usaha simpan pinjam dan cenderung mengabaikan sektor pariwisata yang menyimpan potensi yang cukup besar (Agunggunanto dkk, 2016). Pemilihan usaha yang beragam sesuai dengan potensi lokal yang dimiliki diharapkan dapat meningkatan keuntungan yang didapat dan menyediakan lapangan kerja baru sehingga dapat meningkatkan perekonomian masyarakat.

Selain pertanian, terdapat sektor potensial lainnya yang belum tersentuh BUMDes, seperti pengelolaan sampah dan wisata. Sampah adalah salah satu masalah lingkungan hidup yang belum dapat teratasi. Bahkan di tahun 2019, jumlah timbulan sampah yang dapat didaur ulang mengalami penurunan sebesar $24,54 \%$. Sementara itu, kapasitas Tempat Pembuangan Akhir (TPA) hanya mampu menampung sampah dari wilayah perkotaan dan jumlah kelompok pengelola sampah aktif masih terbatas (RKPD, 2021). Pariwisata adalah sektor potensial selanjutnya dan merupakan salah satu unggulan daerah. Beberapa desa telah berhasil mengembangkan destinasi wisata alam namun pengelolaannya tidak dilakukan bersama BUMDes. Menurut Informan 3, pemilihan unit usaha yang dijalankan oleh BUMDes menjadi cerminan ketidakmampuan pengurus dan pemerintah desa dalam mengidentifikasi potensi desa yang akan dikembangkan menjadi unit usaha. Sebagian besar desa memilih unit usaha sebagaimana yang tercantum dalam contoh proposal pengajan BUMDes yang disediakan oleh Dinas Pemberdayaan Masyarakat Desa. Kondisi tersebut selanjutnya membuat tujuan pendirian BUMDes tidak tercapai. Namun demikian, kondisi tersebut mulai diperbaiki. Beberapa BUMDes mulai mengembangkan unit usaha setelah sebelumnya mengidentifikasi potensi yang dimiliki, seperti BUMDes Desa Tunggul Sari, Kecamatan Tayu yang mengembangkan unit usaha pengelolaan mangrove, BUMDes Desa Kajen, Kecamatan Margoyoso yang memiliki unit usaha pengelolaan sampah untuk mengatasi timbulan sampah dari pesantren-pesantren, dan BUMDes Desa Ngemplak, Kecamatan Margoyoso yang mengembangkan usaha pengelolaan sampah organik.

Pemasaran juga menjadi tantangan pengembangan BUMDes pada dimensi usaha. Sebagian besar BUMDes memiliki cakupan pemasaran terbatas, yaitu wilayah desa. Sosialisasi berkaitan dengan keberadaan BUMDes beserta unit usaha yang dimiliki belum dilakukan secara optimal. Menurut Informan 3, masyarakat desa relatif kurang rasa memiliki 
BUMDes, menyebabkan kurangnya upaya untuk bersama-sama mengembangkan BUMDes. Informan 2 menambahkan proses pembentukan BUMDes, walaupun melalui Musdes, cenderung tidak diwakili oleh seluruh kelompok masyarakat. Hal tersebut memunculkan persepsi dalam sebagian masyarakat bahwa BUMDes merupakan milik kelompok tertentu sehingga enggan untuk memanfaatkan BUMDes. Peran masyarakat memiliki peran yang sangat penting untuk memastikan keberlangsungan usaha BUMDes. Keterlibatan tersebut hendaknya sudah dimulai dari proses perencanaan BUMDes dengan mengumpulkan informasi berkaitan dengan kebutuhan serta potensi yang dimiliki dimiliki oleh masyarakat. Informasi tersebut diharapkan dapat menjadi landasan dalam memilih unit usaha yang akan dijalankan oleh BUMDes. Selain itu, keterlibatan masyarakat dapat memunculkan rasa memiliki dan tanggung jawab atas kelangsungan usaha BUMDes (Faedlulloh, 2018). Selain belum optimlanya partisipasi masyarakat sekitar, rendahnya intensitas kerjasama BUMDes dengan BUMDes lain maupun pihak ketiga menjadi kendala lain yang menjadikan cakupan pemasaran BUMDes terbatas. Hal tersebut menjadikan potensi desa yang telah terolah tidak terpasarkan secara optimal.

Dimensi terkahir yang menjadi sumber masalah pengembangan BUMDes di Kabupaten Pati adalah aturan/legalitas dengan nilai rata-rata 2,00 dari nilai maksimal 4,00. Menurut Informan 1, seluruh BUMDes di Kabupaten Pati yang ada hingga kini, belumberstatus hukum karena masih menggunakan peraturan desa (Perdes) untuk legalitas pendiriannya dan Surat Keputusan Kades untuk penetapan pengurusnya. Hal ini menjadi salah satu kendala dalam pengembangan BUMDes terutama ketika BUMDes ingin mengembangkan usaha dan bekerja sama dengan pihak lain. Kelemahan lainnya adalah hampir seluruh BUMDes di Kabupaten Pati belum memiliki Standar Operasional Prosedur (SOP) yang menjadi pedoman dalam pengelolaan BUMDes.

\section{SIMPULAN}

Hasil penelitian menunjukkan bahwa sebagian besar BUMDes di Kabupaten Pati memiliki berbagai kendala yang berpotensi menjadi hambatan dalam pengelolaan BUMDes. Berdasarkan status keaktifannya, lebih dari 10\% BUMDes di Kabupaten Pati berada pada status tidak aktif, dengan persentase tertinggi berada di Kecamatan Margorejo. Unit usaha yang dijalankan oleh sebagian besar BUMDes adalah usaha jasa, khususnya simpan pinjam. Sementara itu, tercatat hanya beberapa BUMDes yang memiliki unit usaha berbasis potensi desa. Berdasarkan kriteria Pengembangan BUMDes yang dikeluarkan oleh Provinsi Jawa Tengah, kinerja pengembangan BUMDes belum optimal karena sebagian besar BUMDes berada pada kriteria dasar. Hanya terdapat masing-masing satu unit BUMDes yang berada pada kriteria berkembang dan maju.

Permasalahan dalam pengelolaan BUMDes di Kabupaten Pati ditemukan di semua dimensi kriteria pengembangan BUMDes dengan intensitas yang berbeda, yaitu; (1) keterbatasan modal dan aset, (2) Administrasi dan pelaporan yang tidak tertib, (3) Keberadaan BUMDes belum memberikan dampak terhadap masyarakat desa, (4) Kelembagaan yang belum stabil, (5) dan (6) Legalitas BUMDes yang belum kuat. Adapun akar masalah dalam pengembangan BUMDes di Kabupaten Pati adalah keterbatasan kapasitas pengurus BUMDes, situasi politik yang berkembang di desa, rendahnya dukungan pemerintah desa dalam pengembangan BUMDes, serta pengembangan unit usaha yang belum berbasis potensi lokal. 


\section{DAFTAR PUSTAKA}

Agunggunanto, E. ., Arianti, F., Kushartono, E. W., \& Darwanto. (2016). Pengembangan Desa Mandiri Melalui Pengelolaan Badan Usaha Milik Desa (BUMDes). Jurnal Dinamika Ekonomi \& Bisnis, 13(1), 67-81.

Anggraeni, M. R. R. S. (2016). Peranan Badan Usaha Milik Desa (Bumdes) Pada Kesejahteraan Masyarakat Pedesaan Studi Pada Bumdes Di Gunung Kidul, Yogyakarta. Modus, 28(2), 155-167. https://doi.org/ 10.24002/modus.v28i2.848

Badan Pusat Statistik. (2020). Persentase Penduduk Miskin Menurut Wilayah (Persen), 2019-2020. https://bps.go.id/indicator/23/184/1/p ersentase-penduduk-miskin-menurutwilayah.html. Diunduh 28 September 2020.

Badan Pusat Statistik Jawa Tengah. (2020). Persentase Penduduk Miskin (semesteran) (Persen), 2018-2020. https://jateng.bps.go.id/indicator/23/9 7/1/persentase-penduduk-miskinsemesteran-.html. Diunduh tanggal 28 September 2020.

Chikmawati, Z. (2019). Peran BUMDES Dalam Meningkatkan Pertumbuhan Ekonomi Pedesaan Melalui Penguatan Sumber Daya Manusia. Jurnal Istiqro, 5(1), 101-113. https://doi.org/10.30739/istiqro.v5il. 345

Darwita, I. K., \& Redana, N. D. (2018). Peranan Badan Usaha Milik Desa (BUMDes) Dalam Pemberdayaan Masyarakat Dan Penanggulangan Pengangguran di Desa Tejakula Kecamatan Tejakula Kabupaten Buleleng. Locus Majalah Ilmiah FISIP, 9(1), 51-60.

Dinas Pemberdayaan Masyarakat, Desa, Kependudukan, dan Pencatatan Sipil Provinsi Jawa Tengah. Petunjuk
Teknis Klasifikasi Perkembangan

Badan Usaha Milik Desa (BUM Desa) Provinsi Jawa Tengah.

Dinas Pemberdayaan Masyarakat Desa

Kabupaten Pati. (2019). Rekapitulasi

Hasil Penilaian Perkembangan

BUMDes Kabupaten Pati Tahun

2018. Pati: Dispermades.

Dinas Pemberdayaan Masyarakat Desa

Kabupaten Pati. (2020). Rekapitulasi

Hasil Penilaian Indeks Desa

Membangun (IDM) Tahun 2019.

Pati: Dispermades.

Dwidiyantini, K. A., Sulindawati, N. L. G.

E., \& Sujana, E. (2017). Penyusunan

Laporan Keuangan Manufaktur Pada

Badan Usaha Milik Desa (Bumdes)

Tugu Sari Pajahan Kecamatan Pupuan Kabupaten Tabanan. JIMAT

(Jurnal Ilmiah Mahasiswa Akuntansi S1), 7(1).

Faedlulloh, D. (2018). BUMDes dan Kepemilikan Warga: Membangun Skema Organisasi Partisipatoris. Journal of Governance, 3(1), 1-17. https://doi.org/10.31506/jog.v3i1.303 5

Ferosa, M. I., \& Hapsari, A. N. S. (2020). Analisis Kendala Pengelolaa BUMDes Desa Kopeng Kabupaten Semarang. In Proceeding Seminar Nasional (pp. 236-254). Surakarta: Uniba Press.

Firdaus, S. (2018). Fenomena Elite Capture dalam Pengelolaan Badan Usaha Milik Desa (BUMDes): Studi kasus strategi bekerjanya kekuasaan elite dalam pengelolaan BUMDes Argosari, Desa Pulosari, Kabupaten Pemalang. Politika, 9(2), 20-37. Retrieved from http://www. worldbank.org/en/topic/communitydr ivendevelopment/overview\#1

Kinasih, I., Widiyahseno, B., \& Wahjuni DJ, E. (2020). Badan Usaha Milik Desa (BUMDes) dalam memperkuat perekonomian masyarakat. Jurnal 
Administrasi Pemerintahan Desa, 1(1), 33-44. https://doi.org/ 10.32669/villages.v1i1.11

Peraturan Bupati Pati Nomor 1 Tahun 2018 tentang Rencana Pembangunan Jangka Menengah Kabupaten Pati Tahun 2017-2022.

Peraturan Daerah Kabupaten Pati Nomor 4 Tahun 2013 tentang Tata Cara Pembentukan dan Pengelolaan BUMDes.

Peraturan Menteri Desa PDTT Nomor 4 Tahun 2015 tentang Pendirian Badan Usaha Milik Desa.

Prasetyo, R. A. (2016). Peranan Bumdes Dalam Pembangunan dan Pemberdayaan Masyarakat Di Desa Pejambon Kecamatan Sumberrejo, Kabupaten Bojonegoro. Jurnal Dialektika, 11(1), 86-100.

Priyanto, S. H., Nadapdap, H. Y., \& Jansen, A. (2019). Penyusunan Grand Design Pengembangan Badan Usaha Milik Desa (BUMDes) Jawa Tengah (1st ed.). Semarang: Dinas Pemberdayaan Masyarakat, Desa, Kependudukan, dan Pencatatan Sipil Provinsi Jawa Tengah.

Rahmadanik, D. (2018). Peran Bumdes Dalam Pemberdayaan Masyarakat Desa Cokrokembang Kecamatan
Ngadirojo Kabupaten Pacitan. JPAP: Jurnal Penelitian Administrasi Publik, 4(1), 909-913. https://doi.org/ 10.30996/jpap.v4i1.1293

Ridlwan, Z. (2014). Urgensi Badan Usaha Milik Desa (Bumdes) Dalam Pembangun Perekonomian Desa. Ridlwan, Zulkarnain, 8(3), 424-440. https://doi.org/10.25041/fiatjustisia.v 8no3.314

Rozikin, M. (2019). Memperkuat Ketahanan Masyarakat Berbasis Social Capital Pada Era Otonomi Desa (Studi di Desa Pandansari, Kecamatan Ngantang, Kabupaten Malang). Jurnal Ketahanan Nasional, 25(2), 204-225. https:// doi.org/10.22146/jkn.44904

Undang-Undang Nomor 6 Tahun 2014 tentang Desa

Wilonoyudho, S. (2009). Kesenjangan dalam Pembangunan Kewilayahan. Forum Geografi, 23(2), 167-180. https://doi.org/10.23917/forgeo.v23i2 .5009

Zuliyah, S. (2010). Strategi Pemberdayaan Masyarakat Desa dalam Menunjang Pembangunan Daerah. Journal of Rural and Development, I(2), 151160. 
